\title{
SCImago, Eigenfactor Score and H5 Index Journal Rank Indicator: Alternatives to the Journal Impact Factor for Water Resources Journals
}

\author{
Shakil Ahmad \\ Deanship of Library Affairs \\ Imam Abdulrahman Bin Faisal University, Saudi Arabia \\ shahmad@iau.edu.sa \\ Md. Sohail \\ Department of Library Services \\ Fiji National University, Fiji \\ sohailmlis@gmail.com \\ Isam Mohammed Abdel-Magid \\ Environmental Engineering Department, College of Engineering, \\ Imam Abdulrahman Bin Faisal University, Saudi Arabia \\ iahmed@iau.edu.sa
}

\begin{abstract}
Objective. This paper investigated the possibility of SCImago Journal Rank (SJR), Eigenfactor Score (ES) and H5 Index indicators as alternatives to the Journal Impact Factor (JIF) in the field of water resources.

Method. The SJR, ES, H5 index and JIF scores and ranking of water resources journals were downloaded from the relevant websites. Pearson and Spearman correlation coefficients were calculated to test hypotheses for association between the four journal quality metrics.

Result. Strong positive correlations were found between the scores and rank order based on the SJR, ES, H5 and JIF of selected journals. Hence, academics and researchers in water resources can use the SJR, ES and H5 indicators as alternatives to JIF for evaluation and judgment of scientific journals in the area.
\end{abstract}

\section{INTRODUCTION}

This paper reports a comparative study of journal quality indicators accepted by scientific and academic groups for assessment and appraisal of scientific journals in the field of water resources. The main objective of the study was to evaluate quality indices of journal scientific impact with emphasis on the Journal Impact Factor (JIF), Eigenfactor Score (ES), SCImago Journal Rank indicator (SJR) and H5-Index. Specific water resources journals were selected from the relevant category in the Web of Science (WoS) website. The selected water resources journals possess the standard of quality by virtue of being indexed in the Web of Science and Scopus databases. The 2015 JIFs and ESs were obtained from the Journal 
Citation Report, the SJR from the SCImago Journal, and H5-Index from Google Scholar metrics.

Correlations between the indices were calculated using the Pearson product-moment correlation coefficient (Pearson r) and Spearman rank correlation coefficient (Spearman rho) using the SPSS statistical software. The JIF scores ranged between 5.991 to 0.043; ES varied between 0.078 to as low as 0.00001 ; SJR ranged between 2.772 and 0.120 ; and H5 ranged between 92 and 3. A high Pearson r occurred between the JIF and SJR indicators for journals in this category ( $\mathrm{r}=0.901$ ) and between JIF and H5 indices ( $\mathrm{r}=0.898$ ), while the correlation is moderate between JIF and ES values ( $\mathrm{r}=0.791$ ). Spearman rho rank correlation showed an acceptable and identical correlation between JIF and SJR rankings, JIF and ES rankings, and between JIF and H5-Index for water resources journals (coefficient values of 0.806, 0.806 and 0.811 , respectively). The metrics complement each other when used as cooperative indicators to assess the impact of water resources journals.

\section{LITERATURE REVIEW}

Journal quality metrics (also referred to as bibliometric), such as impact factors, are increasingly being used as measures of researchers' and educators' success and prestige (Brown, 2011). A study of research evaluation measures should highlight similarities within each indicator, indicate differences among alternative indicators, capture similar performance characteristics of highly cited journals, show the degree and type of correlations with indicators, and hence add significant journal informational value (Chang \& McAleer, 2012). Bibliometric indicators that are used to appraise quality ranking for journals use complex algorithms. The perceived research performance of individual researchers is crucial for hiring, firing, tenure and promotion decisions (Chang, McAleer, \& Oxley, 2013). Prominent water resources scientific journals sought to fulfill research publishing quality measures and norms. Such benchmarks are typically determined through scientometric tools and means. Presently applied bibliometric and scientometric indicators include: journal impact factor (JIF), Eigenfactor Score (ES), SCImago Journal Rank indicator (SJR), Article Influence Score (AIS) h5-index, and h5-median. The different bibliometric indicators have their benefits and shortcomings.

The Journal Impact Factor or Eugene Garfield factor (JIF) is the most popular (Franceschet, 2010), and widely used as a proxy of a journal's quality and scientific prestige (Bornmann, Marx, Gasparyan, \& Kitas, 2012). JIF is defined as the recorded number of citations within a certain year for the items published in the journal during the two preceding years, divided by the number of such items. This would be the equivalent of the average citation rate of an item during the first and second calendar year after the year of publication (Cantín, Muñoz, \& Roa, 2015; Lozano, Larivière, \& Gingras, 2012), or the number of current citations to articles published in a specific journal in a two-year period divided by the total number of articles published in the same journal in the corresponding two-year period (de Haan, Hillman, \& Ursprung, 2007).

SCImago research laboratory Journal Rank (SJR) index offers essential scientometric information for a large number of scholarly and professional journals based on data licensed from Elsevier's Scopus database. Especially valuable are its features of weighting the citations received based on the prestige of the citing journals, the (partial) exclusion of journal self-citations, and the broader base of source journals (Jacsó, 2010). Guerrero-Bote and Moya-Anegón (2012) suggested a new size-independent indicator of scientific journal prestige, the SJR2 indicator. This indicator takes into account not only the prestige of the 
citing scientific journal but also its closeness to the cited journal using the cosine of the angle between the vectors of the two journals' co-citation profiles.

The Eigenfactor Score (ES) may be interpreted as measuring the journal influence and it reflects both the number of citations and the prestige of citation source. The main attributes of ES are: exclusion of journal self-citation in its calculation, high emphasis for citations from original works published in top-tier journals and subscription to the concept of large network of citations (Yin, 2011).

The Article Influence Score (AIS) uses the Thomson Reuters ISI Web of Science data for the most highly cited journals in each of the Sciences and Social Sciences. It measures the relative importance of a journal's citation influence on a per-article basis (Chang et al., 2013). It is freely available and ranks journals by a similar algorithm as Google's Page Rank (Kianifar, Sadeghi, \& Zarifmahmoudi, 2014). The AIS is derived from ES and is conceptually similar to IF in that there is a numerator as well as a denominator (i.e. number of citable papers), except that it uses ES (rather than the total number of citations) as the numerator. Thus, dissimilar to IF where all citations are counted equally regardless of their source, in AIS, each citation is multiplied by the "quality" of the citing journals, resulting in greater weight accorded to citations that come from highly cited journals, and less weight to poorly cited journals (Rizkallah \& Sin, 2010).

The H-index, originally proposed by Jorge Hirsh, is the largest number $h$ such that at least $\mathrm{h}$ articles in that publication were cited at least $\mathrm{h}$ times each. The h-core of a publication is a set of top cited $\mathrm{h}$ articles from the publication. The h-median of a publication is the median of the citation counts in its h-core. The h-median is a measure of the distribution of citations to the articles in the h-core (Delgado-López-Cózar \& Cabezas-Clavijo, 2013). The index is launched as a bibliometric tool, free of charge to access, offering the $\mathrm{H}$-index for a wide range of scientific journals and other bibliographic sources (Delgado-López-Cózar \& Cabezas-Clavijo, 2013). The h-index is dependent on the journal's "age”, its visibility and how frequently cited its articles are. The H-index reflects both the number of publications (“productivity") and the number of citations per publication ("impact”) (Leydesdorff, 2009).

Source normalized impact per paper (SNIP) measures a journal's contextual citation impact, taking into account the characteristics of its properly defined subject field, frequency with which authors cite other papers in their reference lists, rapidity of rapidity of citation impact maturity and the extent to which a database used for assessment covers the field's literature. SNIP is defined as the ratio of journal's citation count per paper and the citation potential in its subject field. It aims to allow for the direct comparison of sources in different subject fields. Citation potential is shown to vary not only between journal subject categories - groupings of journals sharing a research field or disciplines (e.g., journals in mathematics, engineering and social sciences tend to have lower values than titles in life sciences), but also between journals within the same subject category (Moed, 2010).

Table 1 gives an overview of the most used quality indicators and their features, including: journal history, journal's indexing in an accredited database, rate of international cooperation, and country of publication, popularity, use in journals advertising, journal's inclusion, inclusion of other citations, inclusion of self-citations, modification abilities, selection flexibility, compatibility with other indicators, information management, easiness of use, self-citations limitations, online access, English language bias, free availability, single journals assignments category, developer, quality assessment algorithm, metrics ranking and time window. 
Table 1. Common bibliometric journal indicators and their features

\begin{tabular}{|c|c|c|c|c|c|c|c|}
\hline $\begin{array}{l}\text { Bibliometric } \\
\text { features, } \\
\text { requirements, } \\
\text { functionality, } \\
\text { use }\end{array}$ & $\begin{array}{l}\text { Journal } \\
\text { Impact } \\
\text { factor } \\
\text { (JIF) }\end{array}$ & $\begin{array}{c}\text { SCImago } \\
\text { journal } \\
\text { rank } \\
\text { indicator } \\
\text { (SJR) }\end{array}$ & SJR2 & $\begin{array}{l}\text { Eigenfact } \\
\text {-or Score }\end{array}$ & $\begin{array}{c}\text { H-index } \\
\text { (h5-index } \\
\text { and h5- } \\
\text { median) }\end{array}$ & $\begin{array}{c}\text { Article } \\
\text { Influence } \\
\text { Score } \\
\text { (AIS) }\end{array}$ & SNIP \\
\hline Popularity & $\bullet$ & $\bullet$ & & & $\bullet$ & & \\
\hline $\begin{array}{l}\text { Use in journals } \\
\text { advertising }\end{array}$ & $\bullet$ & $\bullet$ & & $\bullet$ & $\bullet$ & & \\
\hline $\begin{array}{l}\text { Journal's } \\
\text { inclusion }\end{array}$ & & $\bullet$ & & & & & \\
\hline $\begin{array}{l}\text { Inclusion of } \\
\text { other citations } \\
\text { (editorials, } \\
\text { letters, etc.) }\end{array}$ & $\bullet$ & & & & & & \\
\hline $\begin{array}{l}\text { Closeness to the } \\
\text { cited journal }\end{array}$ & & & $\bullet$ & & & & \\
\hline $\begin{array}{l}\text { Inclusion of } \\
\text { self-citations }\end{array}$ & $\bullet$ & & & & & & \\
\hline $\begin{array}{l}\text { Modification } \\
\text { abilities }\end{array}$ & $\bullet$ & $\bullet$ & & $\bullet$ & & & \\
\hline $\begin{array}{l}\text { Selection } \\
\text { flexibility }\end{array}$ & $\bullet$ & $\bullet$ & & $\bullet$ & $\bullet$ & & \\
\hline $\begin{array}{l}\text { Compatibility } \\
\text { with indicators }\end{array}$ & $\bullet$ & $\bullet$ & & $\bullet$ & $\bullet$ & $\bullet$ & $\bullet$ \\
\hline $\begin{array}{l}\text { Information } \\
\text { management }\end{array}$ & $\bullet$ & $\bullet$ & - & & & & \\
\hline Easiness of use & $\bullet$ & $\bullet$ & & $\bullet$ & $\bullet$ & & \\
\hline $\begin{array}{l}\text { Self-citations } \\
\text { limitations }\end{array}$ & & $\bullet$ & & & & & \\
\hline Online access & & $\bullet$ & & & & & \\
\hline $\begin{array}{l}\text { English } \\
\text { language bias }\end{array}$ & - & & & & & & \\
\hline Free availability & & $\bullet$ & & $\bullet$ & & $\bullet$ & \\
\hline $\begin{array}{l}\text { Single journals } \\
\text { assignments } \\
\text { category }\end{array}$ & & & & - & & & \\
\hline $\begin{array}{l}\text { Institute for } \\
\text { Scientific } \\
\text { Information } \\
\text { (ISI) developer }\end{array}$ & $\bullet$ & & & & & & \\
\hline $\begin{array}{l}\text { Scopus database } \\
\text { [Elsevier]. } \\
\text { developer }\end{array}$ & & $\bullet$ & & & & & \\
\hline $\begin{array}{l}\text { Google’s Page } \\
\text { Rank developer }\end{array}$ & & & & $\bullet$ & & & $\bullet$ \\
\hline $\begin{array}{l}\text { Scopus, (WoS), } \\
\text { and Google } \\
\text { Scholar } \\
\text { Citations } \\
\text { developer }\end{array}$ & & & & & $\bullet$ & $\bullet$ & \\
\hline $\begin{array}{l}\text { Thomson } \\
\text { Reuters ISI Web } \\
\text { of Science data }\end{array}$ & & & & & & $\bullet$ & \\
\hline
\end{tabular}

Continued.. 


\begin{tabular}{|c|c|c|c|c|c|c|c|}
\hline $\begin{array}{l}\text { Bibliometric } \\
\text { features, } \\
\text { requirements, } \\
\text { functionality, use }\end{array}$ & $\begin{array}{c}\text { Journal } \\
\text { Impact } \\
\text { factor } \\
\text { (JIF) }\end{array}$ & $\begin{array}{l}\text { SCImago } \\
\text { journal } \\
\text { rank } \\
\text { indicator } \\
\text { (SJR) } \\
\end{array}$ & SJR2 & $\begin{array}{l}\text { Eigenfact- } \\
\text { or Score }\end{array}$ & $\begin{array}{l}\text { H-index } \\
\text { (h5- } \\
\text { index } \\
\text { and h5- } \\
\text { median) }\end{array}$ & $\begin{array}{c}\text { Article } \\
\text { Influence } \\
\text { Score } \\
\text { (AIS) }\end{array}$ & SNIP \\
\hline $\begin{array}{l}\text { Cosine of the angle } \\
\text { between the } \\
\text { vectors of the two } \\
\text { journals' co- } \\
\text { citation profiles }\end{array}$ & & & $\bullet$ & & & & \\
\hline $\begin{array}{l}\text { PageRank } \\
\text { algorithm }\end{array}$ & & $\bullet$ & & & & & \\
\hline $\begin{array}{l}\text { Quality assessment } \\
\text { algorithm }\end{array}$ & & & & • & & & \\
\hline $\begin{array}{l}\text { Google Scholar } \\
\text { Metrics ranking }\end{array}$ & & & & & $\bullet$ & & \\
\hline $\begin{array}{l}\text { Time window, } \\
\text { previous } 3 \text { years }\end{array}$ & & • & & & & & \\
\hline $\begin{array}{l}\text { Time window, } \\
\text { previous } 5 \text { years }\end{array}$ & & & & $\bullet$ & & & \\
\hline
\end{tabular}

Sources: Abrizah, Zainab, Kiran, \& Raj, 2013; Ahmad, Abdel-Magid, \& Abdel-Magid, 2016; Cantín, Munoz \& Roa, 2015; Elkins, Maher, Herbert, Moseley, \& Sherrington, 2010; Franchignoni \& Lasa, 2011; García-Pachón \& Arencibia-Jorge, 2014; Guerrero-Bote \& Moya-Anegón, 2012; Jamali, Salehi-Marzijarani, \& Ayatollahi, 2014; Ram, Kataria, \& Ahmad, 2014; Ramin \& Shirazi, 2012; Zarifmahmoudi, Jamali, \& Sadeghi, 2015

\section{METHOD}

Pertinent information for the selected water resources journals was obtained from the journal ranking section of SCImago journal and country ranking website 1 and from Web of Science2 (WoS) Core Collection official website. ISI indexed journals were used for computation of impact factor. The 2015 JIFs and ESs were acquired from the Journal Citation Report (JCR) through WoS. The 2015 SJR indicator is offered by the SCImago Journal, and country rank provided by Scopus and Google Scholar Citations (GS) metrics under the category of Water resources. Journals with JIFs and ESs were tabulated, and information regarding their ranking in the SJR indicator list was retrieved by matching their ISSN. Likewise, journals with the SJR indicators were listed and their ranking was identified in the inventory of journal JIFs.

The ranks of each journal according to each metric were also compared statistically. The correlations between the extracted indices were evaluated using both Pearson and Spearman correlation coefficients. All analyses were conducted using the Statistical Package for the Social Sciences (SPSS) 21.0, version 2012.

Eighty-five journals were identified with water resources as the specific scope and focus. They are listed in the Appendix, together with their scores and rankings according to SCImago, JIF, ES and H5-Index in 2015.

The information in the Appendix indicates that none of the selected water resources journals had the same ranking in all four classifications and metrics indices under review. All investigated journals are high quality journals since they are indexed in the two most prestigious databases, WoS and Scopus.

\footnotetext{
${ }^{1}$ http://www.scimagojr.com/

2 http://www.accesowok.fecyt.es/
} 


\section{RESULTS AND DISCUSSION}

Following the JIF indicator, the top three most cited journals were Water Research (JIF 5.991), Water Research and Desalination (JIF 4.412) and Advances in Water Resources (JIF 4.349). These were closely followed by Chemical Engineering Journal (JIF 5.31). In contrast, the lowest citations were obtained by Wasserwirtschaft (JIF 0.102) and Tecnologia Y Ciencias Del Agua (JIF0.043).

Following the Eigenfactor Score, the journals that ranked top three were Water Research (ES 0.0782), Water Resources Research (ES 0.05653) and Journal of Hydrology (ES 0.04961). Lowest ES were recorded for Tecnologia Y Ciencias Del Agua (ES 0.00008) and Environmental Science-Water Research and Technology (ES 0.00001).

The SJR indicator agreed with JIF in ranking the top three as Water Research (SJR 2.772) Environmental Science \& Technology (SJR 2.664) and Applied Catalysis BEnvironmental (SJR 2.322). Geomatics Natural Hazards and Risk brought up the rear (SJR $0.12)$.

The top three journals following the H5 index were Water Research (H5 of 92), followed by Desalination (H5 of 83), with Water Resources Research and Journal of Hydrology tying for third place (H5 of 64). Hydrologie Und Wasserbewirtschaftung was last with an $\mathrm{H} 5$ index of 3.

Table 2 lists the bivariate correlation between the four indicators (JIF, ES, SJR and H5) for the water resources journals. There is a high Pearson correlation between JIF and SJR indicators ( $\mathrm{r}=0.901$ ), and between JIF and H5 indices ( $\mathrm{r}=0.898$ ). JIF and ES obtained a moderately high correlation of $r=0.791$. With respect to Spearman rho rank correlation, an acceptably high correlation obtained between JIF and SJR rankings, JIF and ES, and between JIF and H5-Index (coefficient values of 0.806, 0.806 and 0.811 respectively).

The results suggest that the use of the SJR index does not substantially modify the classification of water resources journals from the JIF indicator. Since SCImago Journal and Country Rank is accessible for free, SJR may be considered as an alternative to JIF for water resources journals. This finding is in agreement with García-Pachón and Arencibia-Jorge (2014) and Ahmad et al. (2016).

Figure 1 depicts a bump chart for the top ten JIF ranked water resources journals in comparison with SJR ranking. The figure clearly shows the changing pattern of both indicators for the selected water resources journals. The Journal of Environmental Toxicology and Catena underwent the greatest change.

Figure 2 shows a bump chart for the top ten JIF ranked water resources journals in comparison with ES ranking. The first eight journals showed reasonable correlation and fluctuation between the two indices. The journals Agricultural Water Management and Hydrological Processes suffered the greatest differences.

Figure 4 shows scatter plots showing correlation of values and rankings between JIF, ES and SJR, as well as their fit lines for 85 water resources journals. A linear correlation between the different indices (ES versus JIF and SJR versus JIF) is clearly revealed in the figure. Likewise, linearity of relationship is obvious between both ranks of ES versus JIF, and of SJR versus JIF as shown in Figure 3. 


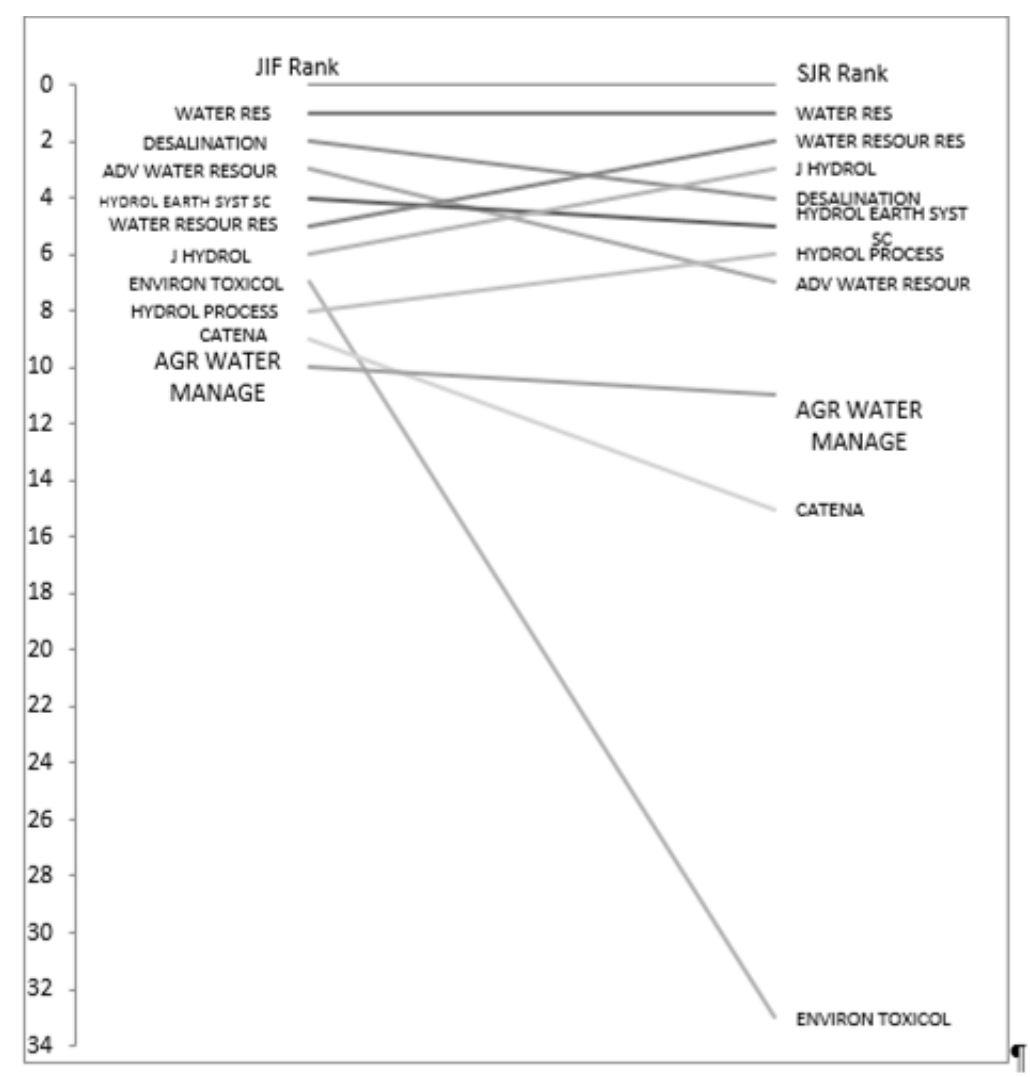

Figure 1. Bump chart for the top $10 \mathrm{JIF}$ ranked Water Resources journals in comparison with SJR ranking

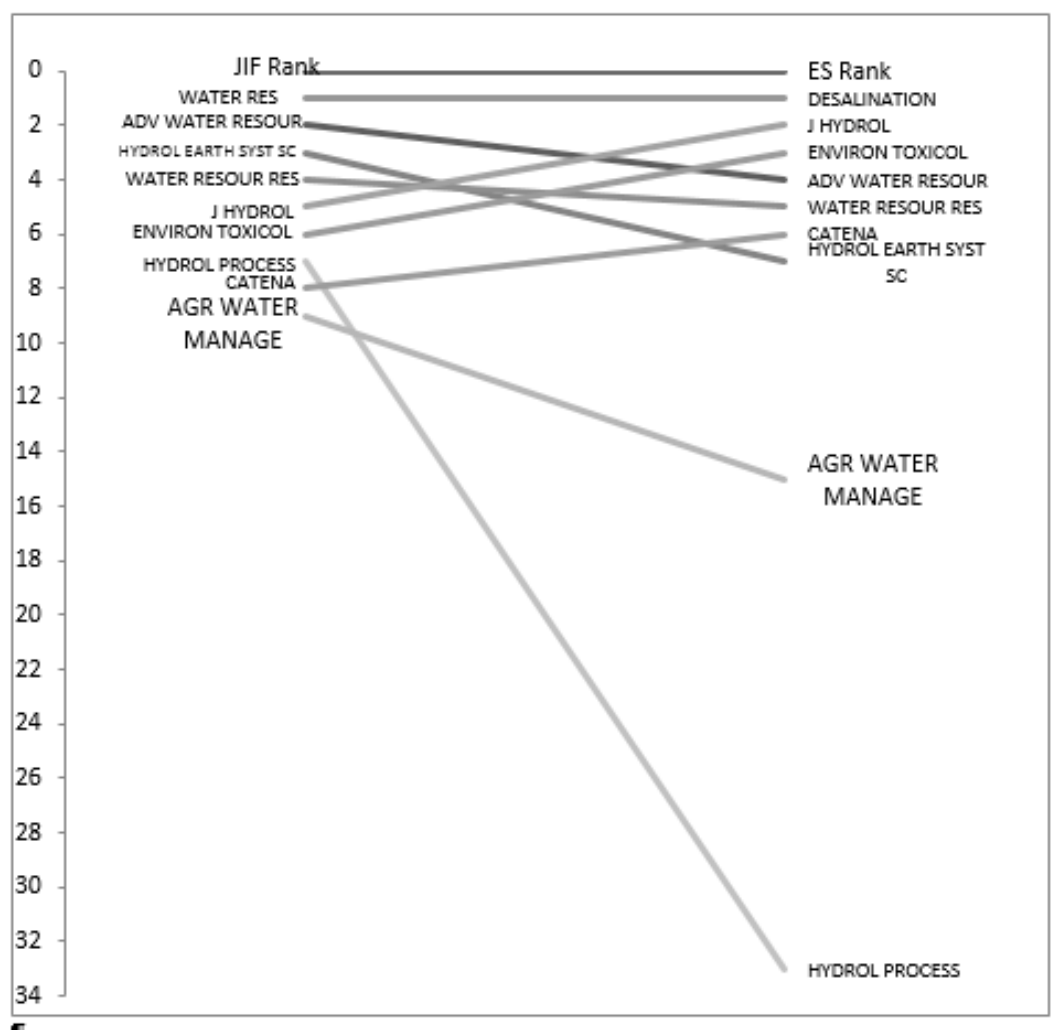

Figure 2. Bump chart for the top $10 \mathrm{JIF}$ ranked Water Resources journals in comparison with ES ranking 


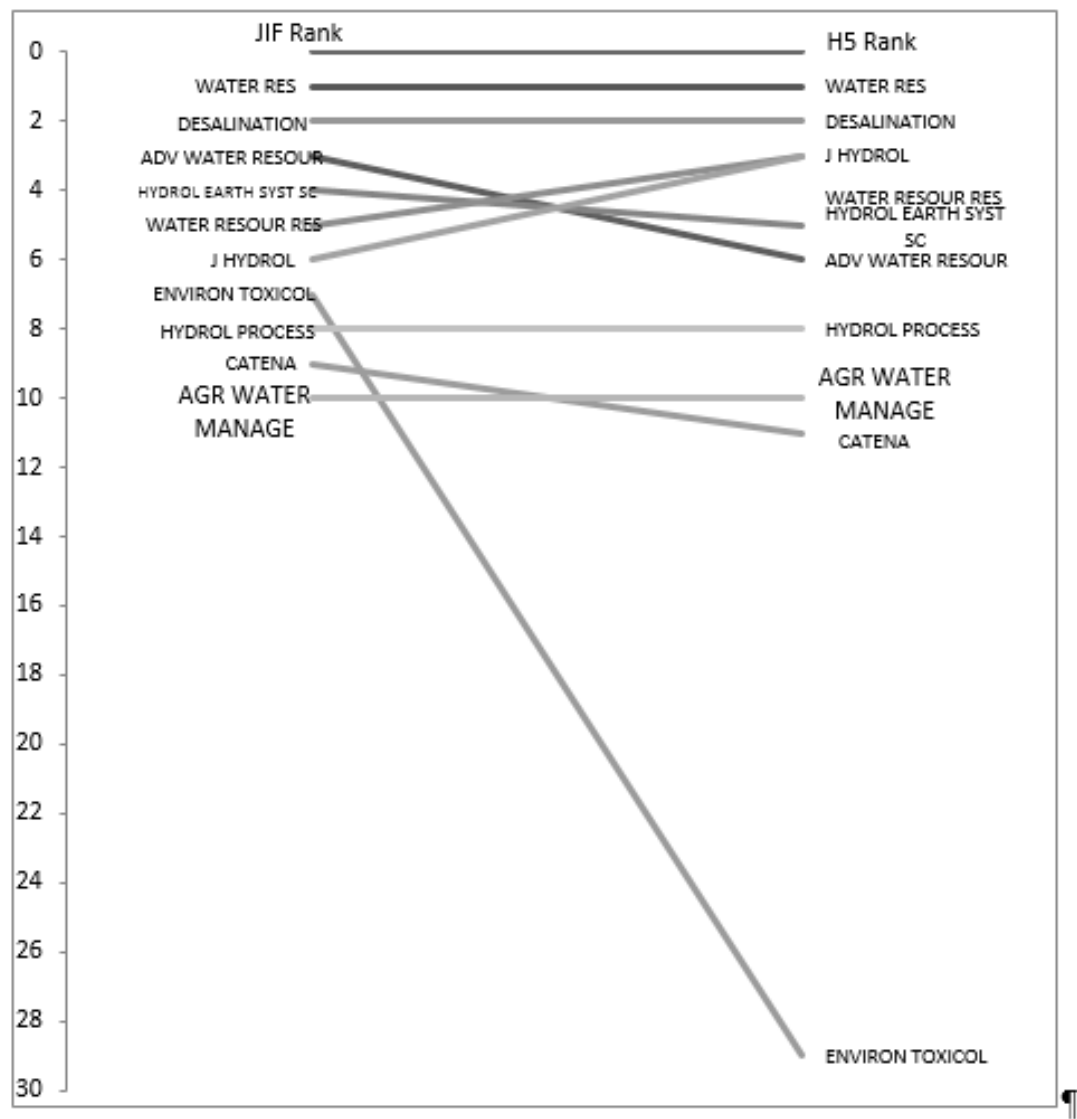

Figure 3. Bump chart for the top $10 \mathrm{JIF}$ ranked Water Resources journals in comparison with $\mathrm{H} 5$ ranking

\section{CONCLUSION}

The study has compared four journals qualities indices_JIF, SJR, ES and H5-Index for water resources journals. The Journal Impact Factor (JIF) is the chief index used by researchers and academicians for ranking water resources journals. While a number of shortcomings appear in using only the JIF indicator, the SJR and ES could be more precise quality indices for water resources journals. It is recommended to use all four indices when measuring the quality of water resources journals. All the four metrics are highly correlated with one another (Spearman's rho $>0.8$ )

JIF, ES and SJR indicators of journals are important for librarians, researchers, academicians, authors, writers, inventors and environmental engineers alike when targeting quality journals for publishing their work. All the analyzed water resources journals possess the standard of quality of being indexed in esteemed databases such as Web of Science (WoS) and Scopus. A high Pearson r correlation was obtained between JIF and SJR indicators $(\mathrm{r}=0.901)$ and between JIF and $\mathrm{H} 5$ indices $(\mathrm{r}=0.898)$, while a moderately high correlation was found between JIF and ES values ( $\mathrm{r}=0.791)$. Spearman rho rank correlation found acceptable correlations between JIF and SJR rankings, JIF and ES rankings, and JIF and H5 rankings (coefficient values of $0.806,0.806$ and 0.811 respectively). The metrics may be taken as complementary in assessing the quality and impact of water resources journals. 

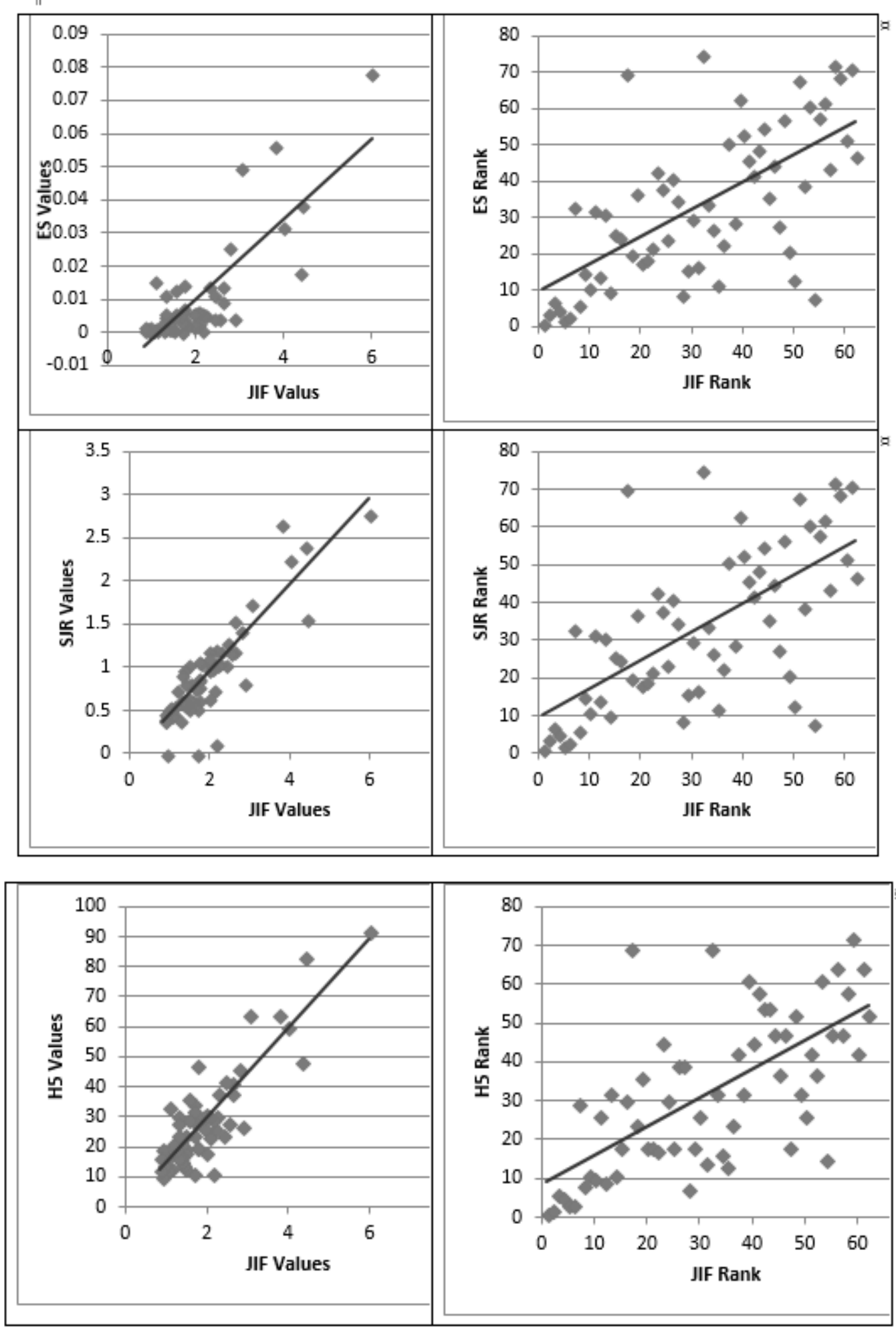

Figure 4. Scatter plots showing correlation between JIF, ES, SJR and H5-Index (values and rankings) as well as their fit lines for 60 Water Resources journals 
Table 2. Bivariate correlations between the four indicators for ranking water resources journals

\begin{tabular}{l|c|c}
\hline Correlation statistic & Coefficient value & Sig. \\
\hline Pearson r between JIF and ES values & 0.791 & .000 \\
Pearson r between JIF and SJR values & 0.901 & .000 \\
Pearson r between JIF and H5 values & 0.898 & .000 \\
Spearman rho between JIF and ES rankings & 0.806 & .000 \\
Spearman rho between JIF and SJR rankings & 0.806 & .000 \\
Spearman rho between JIF and H5 rankings & 0.841 & .000 \\
\hline
\end{tabular}

\section{REFERENCES}

Abrizah, A., Zainab, A., Kiran, K., \& Raj, R. (2013). LIS journals scientific impact and subject categorization: A comparison between Web of Science and Scopus. Scientometrics, 94(2), 721-740.

Ahmad, S., Abdel-Magid, M.I.M., \& Abdel-Magid, I.M. (2016). Comparison between Impact Factor, SCImago Journal Rank Indicator and Eigenfactor Score of civil engineering journals. Sudan Engineering Society Journal, 62(1), 31-43.

Ahmad, S., Magid, E.T.I.M.A., Magid, C.I.M.A., \& Waris, A. (2017). Comparison among selected journal quality indicators of mechanical engineering journals. Journal of Scientometric Research, 6(3), 151-158.

Bornmann, L., Marx, W., Gasparyan, A. Y., \& Kitas, G. D. (2012). Diversity, value and limitations of the journal impact factor and alternative metrics. Rheumatology International, 32(7), 1861-1867.

Brown, T. (2011). Journal quality metrics: Options to consider other than impact factors. American Journal of Occupational Therapy, 65(3), 346-350.

Cantín, M., Muñoz, M., \& Roa, I. (2015). Comparison between Impact Factor, Eigenfactor Score, and SCImago Journal Rank Indicator in anatomy and morphology journals. International Journal of Morphology, 33(3).

Chang, C.-L., \& McAleer, M. (2012). Citations and impact of ISI tourism and hospitality journals. Tourism Management Perspectives, 1, 2-8.

Chang, C.-L., McAleer, M., \& Oxley, L. (2013). Coercive journal self citations, impact factor, journal influence and article influence. Mathematics and Computers in Simulation, 93, 190-197.

de Haan, J., Hillman, A.L., \& Ursprung, H.W. (2007). Impact factor comparisons for the European Journal of Political Economy. European Journal of Political Economy, 23(3), 581.

Delgado-López-Cózar, E., \& Cabezas-Clavijo, Á. (2013). Ranking journals: could Google scholar metrics be an alternative to journal citation reports and SCImago journal rank? Learned publishing, 26(2), 101-113.

Elkins, M.R., Maher, C.G., Herbert, R.D., Moseley, A.M., \& Sherrington, C. (2010). Correlation between the journal impact factor and three other journal citation indices. Scientometrics, 85(1), 81-93.

Franceschet, M. (2010). Journal influence factors. Journal of Informetrics, 4(3), 239-248.

Franchignoni, F., \& Lasa, S.M. (2011). Bibliometric indicators and core journals in physical and rehabilitation medicine. Journal of Rehabilitation Medicine, 43(6), 471-476. 
García-Pachón, E., \& Arencibia-Jorge, R. (2014). A comparison of the impact factor and the SCImago Journal Rank index in respiratory system journals. Archivos de bronconeumologia, 50(7), 308-309.

Guerrero-Bote, V.P., \& Moya-Anegón, F. (2012). A further step forward in measuring journals' scientific prestige: The SJR2 indicator. Journal of Informetrics, 6(4), 674688.

Jacsó, P. (2010). Comparison of journal impact rankings in the SCImago Journal \& Country Rank and the Journal Citation Reports databases. Online Information Review, 34(4), 642-657.

Jamali, J., Salehi-Marzijarani, M., \& Ayatollahi, S.M.T. (2014). Factors affecting journal quality indicator in scopus (SCImago journal rank) in obstetrics and gynecology journals: A longitudinal study (1999-2013). Acta Informatica Medica, 22(6), 385.

Kianifar, H., Sadeghi, R., \& Zarifmahmoudi, L. (2014). Comparison between impact factor, Eigenfactor metrics, and SCImago journal rank indicator of pediatric neurology journals. Acta Informatica Medica, 22(2), 103.

Leydesdorff, L. (2009). How are new citation-based journal indicators adding to the bibliometric toolbox? Journal of the Association for Information Science and Technology, 60(7), 1327-1336.

Lozano, G. A., Larivière, V., \& Gingras, Y. (2012). The weakening relationship between the impact factor and papers' citations in the digital age. Journal of the Association for Information Science and Technology, 63(11), 2140-2145.

Moed, H. F. (2010). Measuring contextual citation impact of scientific journals. Journal of Informetrics, 4(3), 265-277.

Ram, S., Kataria, S., \& Ahmad, S. (2014). An assessment of the visibility of Indian journals in social science citation index-journal citation report. Journal of Information Management, 1(1), 1-17.

Ramin, S., \& Shirazi, A.S. (2012). Comparison between Impact factor, SCImago journal rank indicator and Eigenfactor Score of nuclear medicine journals. Nuclear Medicine Review, 15(2), 132-136.

Rizkallah, J., \& Sin, D.D. (2010). Integrative approach to quality assessment of medical journals using Impact Factor, Eigenfactor, and Article Influence Scores. PloS one, 5(4), e10204.

Yin, C.-Y. (2011). Do impact factor, h-index and Eigenfactor ${ }^{\mathrm{TM}}$ of chemical engineering journals correlate well with each other and indicate the journals' influence and prestige? Current Science, 2011, 648-653.

Zarifmahmoudi, L., Jamali, J., \& Sadeghi, R. (2015). Google scholar journal metrics: Comparison with impact factor and scimago journal rank indicator for nuclear medicine journals. Iranian Journal of Nuclear Medicine, 23(1), 8-14. 
APPENDIX.

Comparative rankings of Water Resources journals by 2015 JIF, ES, SJR and H5 Index

\begin{tabular}{|c|c|c|c|c|c|c|c|c|}
\hline \multirow[b]{2}{*}{ Journal } & \multicolumn{2}{|c|}{$\begin{array}{l}\text { Journal Impact } \\
\text { Factor (JIF) }\end{array}$} & \multicolumn{2}{|c|}{$\begin{array}{l}\text { Eigenfactor } \\
\text { Score (ES) }\end{array}$} & \multicolumn{2}{|c|}{$\begin{array}{l}\text { SCImago } \\
\text { Journal Rank } \\
\text { (SJR) }\end{array}$} & \multicolumn{2}{|c|}{ H-5 Index } \\
\hline & Value & Rank & Value & Rank & Value & Rank & Value & Rank \\
\hline Water Research & 5.991 & 1 & 0.0782 & 1 & 2.772 & 1 & 92 & 1 \\
\hline Desalination & 4.412 & 2 & 0.0385 & 4 & 1.549 & 4 & 83 & 2 \\
\hline $\begin{array}{l}\text { Advances in Water } \\
\text { Resources }\end{array}$ & 4.349 & 3 & 0.01833 & 7 & 2.408 & 7 & 48 & 6 \\
\hline $\begin{array}{l}\text { Hydrology and Earth } \\
\text { System Sciences }\end{array}$ & 3.99 & 4 & 0.03215 & 5 & 2.257 & 5 & 60 & 5 \\
\hline $\begin{array}{l}\text { Water Resources } \\
\text { Research }\end{array}$ & 3.792 & 5 & 0.05653 & 2 & 2.661 & 2 & 64 & 3 \\
\hline Journal of Hydrology & 3.043 & 6 & 0.04961 & 3 & 1.743 & 3 & 64 & 3 \\
\hline $\begin{array}{l}\text { Environmental } \\
\text { Toxicology }\end{array}$ & 2.868 & 7 & 0.00431 & 33 & 0.819 & 33 & 27 & 29 \\
\hline Hydrological Processes & 2.768 & 8 & 0.02584 & 6 & 1.419 & 6 & 46 & 8 \\
\hline Catena & 2.612 & 9 & 0.0095 & 15 & 1.191 & 15 & 38 & 11 \\
\hline $\begin{array}{l}\text { Agricultural Water } \\
\text { Management }\end{array}$ & 2.603 & 10 & 0.01394 & 11 & 1.546 & 11 & 41 & 10 \\
\hline $\begin{array}{l}\text { Journal of Water } \\
\text { Resources Planning and } \\
\text { Management }\end{array}$ & 2.521 & 11 & 0.00435 & 32 & 1.173 & 32 & 28 & 26 \\
\hline $\begin{array}{l}\text { Water Resources } \\
\text { Management }\end{array}$ & 2.437 & 12 & 0.01131 & 14 & 1.291 & 14 & 42 & 9 \\
\hline $\begin{array}{l}\text { Aquatic Conservation- } \\
\text { Marine and Freshwater } \\
\text { Ecosystems }\end{array}$ & 2.415 & 13 & 0.00437 & 31 & 1.047 & 31 & 24 & 32 \\
\hline $\begin{array}{l}\text { Natural Hazards and } \\
\text { Earth System Sciences }\end{array}$ & 2.277 & 14 & 0.01415 & 10 & 1.189 & 10 & 38 & 11 \\
\hline $\begin{array}{l}\text { Stochastic } \\
\text { Environmental } \\
\text { Research and Risk } \\
\text { Assessment }\end{array}$ & 2.237 & 15 & 0.00521 & 26 & 1.065 & 26 & 30 & 18 \\
\hline $\begin{array}{l}\text { Hydrological Sciences } \\
\text { Journal-Journal Des } \\
\text { Sciences } \\
\text { Hydrologiques }\end{array}$ & 2.182 & 16 & 0.00528 & 25 & 1.04 & 25 & 26 & 30 \\
\hline $\begin{array}{l}\text { Geomatics Natural } \\
\text { Hazards and Risk }\end{array}$ & 2.14 & 17 & 0.00055 & 70 & 0.12 & 70 & 11 & 69 \\
\hline Ecohydrology & 2.138 & 18 & 0.00611 & 20 & 1.213 & 20 & 29 & 24 \\
\hline $\begin{array}{l}\text { Environmental } \\
\text { Geochemistry and } \\
\text { Health }\end{array}$ & 2.079 & 19 & 0.00299 & 37 & 0.729 & 37 & 23 & 36 \\
\hline $\begin{array}{l}\text { Journal of Contaminant } \\
\text { Hydrology }\end{array}$ & 2.063 & 20 & 0.00633 & 18 & 0.993 & 18 & 30 & 18 \\
\hline Hydrogeology Journal & 2.028 & 21 & 0.00625 & 19 & 1.049 & 19 & 30 & 18 \\
\hline $\begin{array}{l}\text { River Research and } \\
\text { Applications }\end{array}$ & 1.98 & 22 & 0.00585 & 22 & 0.984 & 22 & 31 & 17 \\
\hline
\end{tabular}


-ibres volume 27, issue 2, pages 97-111 (2017)

\begin{tabular}{|c|c|c|c|c|c|c|c|c|}
\hline \multirow[b]{2}{*}{ Journal } & \multicolumn{2}{|c|}{$\begin{array}{l}\text { Journal Impact } \\
\text { Factor (JIF) }\end{array}$} & \multicolumn{2}{|c|}{$\begin{array}{l}\text { Eigenfactor } \\
\text { Score (ES) }\end{array}$} & \multicolumn{2}{|c|}{$\begin{array}{l}\text { SCImago } \\
\text { Journal Rank } \\
\text { (SJR) }\end{array}$} & \multicolumn{2}{|c|}{ H-5 Index } \\
\hline & Value & Rank & Value & Rank & Value & Rank & Value & Rank \\
\hline $\begin{array}{l}\text { Journal of Hydro- } \\
\text { Environment Research }\end{array}$ & 1.971 & 23 & 0.00188 & 43 & 0.641 & 43 & 18 & 45 \\
\hline Irrigation Science & 1.948 & 24 & 0.00275 & 38 & 1.193 & 38 & 26 & 30 \\
\hline Groundwater & 1.947 & 25 & 0.00559 & 24 & 1.111 & 24 & 30 & 18 \\
\hline Hydrology Research & 1.779 & 26 & 0.00209 & 41 & 1.053 & 41 & 20 & 39 \\
\hline $\begin{array}{l}\text { Journal of Soil and } \\
\text { Water Conservation }\end{array}$ & 1.752 & 27 & 0.00334 & 35 & 0.888 & 35 & 20 & 39 \\
\hline Natural Hazards & 1.746 & 28 & 0.0149 & 9 & 0.851 & 9 & 47 & 7 \\
\hline Vadose Zone Journal & 1.737 & 29 & 0.00756 & 16 & 1.078 & 16 & 30 & 18 \\
\hline Clean-Soil Air Water & 1.716 & 30 & 0.00446 & 30 & 0.635 & 30 & 28 & 26 \\
\hline $\begin{array}{l}\text { Ocean and Coastal } \\
\text { Management }\end{array}$ & 1.696 & 31 & 0.00656 & 17 & 0.784 & 17 & 34 & 14 \\
\hline $\begin{array}{l}\text { Water Quality } \\
\text { Exposure and Health }\end{array}$ & 1.692 & 32 & 0.00028 & 75 & 0 & 75 & 11 & 69 \\
\hline Water & 1.687 & 33 & 0.0034 & 34 & 0.536 & 34 & 24 & 32 \\
\hline $\begin{array}{l}\text { Journal of the } \\
\text { American Water } \\
\text { Resources Association }\end{array}$ & 1.659 & 34 & 0.00511 & 27 & 0.771 & 27 & 32 & 16 \\
\hline $\begin{array}{l}\text { Water Air and Soil } \\
\text { Pollution }\end{array}$ & 1.551 & 35 & 0.01303 & 12 & 0.632 & 12 & 36 & 13 \\
\hline $\begin{array}{l}\text { Journal of Hydrologic } \\
\text { Engineering }\end{array}$ & 1.53 & 36 & 0.00579 & 23 & 0.819 & 23 & 29 & 24 \\
\hline Urban Water Journal & 1.478 & 37 & 0.00134 & 51 & 0.632 & 51 & 19 & 42 \\
\hline $\begin{array}{l}\text { Journal of Hydraulic } \\
\text { Research }\end{array}$ & 1.471 & 38 & 0.00472 & 29 & 1.022 & 29 & 24 & 32 \\
\hline $\begin{array}{l}\text { Journal of Hydrology } \\
\text { and Hydromechanics }\end{array}$ & 1.469 & 39 & 0.00074 & 63 & 0.538 & 63 & 13 & 61 \\
\hline $\begin{array}{l}\text { International Journal of } \\
\text { Water Resources } \\
\text { Development }\end{array}$ & 1.463 & 40 & 0.0013 & 53 & 0.641 & 53 & 18 & 45 \\
\hline $\begin{array}{l}\text { Wetlands Ecology and } \\
\text { Management }\end{array}$ & 1.407 & 41 & 0.00167 & 46 & 0.565 & 46 & 14 & 58 \\
\hline $\begin{array}{l}\text { Environmental Fluid } \\
\text { Mechanics }\end{array}$ & 1.394 & 42 & 0.00199 & 42 & 0.585 & 42 & 15 & 54 \\
\hline $\begin{array}{l}\text { International Journal of } \\
\text { Sediment Research }\end{array}$ & 1.388 & 43 & 0.00151 & 49 & 0.829 & 49 & 15 & 54 \\
\hline $\begin{array}{l}\text { Journal of Flood Risk } \\
\text { Management }\end{array}$ & 1.377 & 44 & 0.00128 & 55 & 0.587 & 55 & 17 & 47 \\
\hline $\begin{array}{l}\text { Journal of Irrigation } \\
\text { and Drainage } \\
\text { Engineering }\end{array}$ & 1.364 & 45 & 0.00308 & 36 & 0.616 & 36 & 21 & 37 \\
\hline $\begin{array}{l}\text { Journal of Waterway } \\
\text { Port Coastal and Ocean } \\
\text { Engineering }\end{array}$ & 1.316 & 46 & 0.0017 & 45 & 0.977 & 45 & 17 & 47 \\
\hline $\begin{array}{l}\text { Physics and Chemistry } \\
\text { of the Earth }\end{array}$ & 1.297 & 47 & 0.0049 & 28 & 0.611 & 28 & 30 & 18 \\
\hline
\end{tabular}


-ibres volume 27, issue 2, pages 97-111 (2017)

\begin{tabular}{|c|c|c|c|c|c|c|c|c|}
\hline \multirow[b]{2}{*}{ Journal } & \multicolumn{2}{|c|}{$\begin{array}{l}\text { Journal Impact } \\
\text { Factor (JIF) }\end{array}$} & \multicolumn{2}{|c|}{$\begin{array}{l}\text { Eigenfactor } \\
\text { Score (ES) }\end{array}$} & \multicolumn{2}{|c|}{$\begin{array}{l}\text { SCImago } \\
\text { Journal Rank } \\
\text { (SJR) }\end{array}$} & \multicolumn{2}{|c|}{ H-5 Index } \\
\hline & Value & Rank & Value & Rank & Value & Rank & Value & Rank \\
\hline $\begin{array}{l}\text { Natural Hazards } \\
\text { Review }\end{array}$ & 1.293 & 48 & 0.00116 & 57 & 0.639 & 57 & 16 & 52 \\
\hline $\begin{array}{l}\text { Journal of Hydraulic } \\
\text { Engineering }\end{array}$ & 1.284 & 49 & 0.0059 & 21 & 0.908 & 21 & 24 & 32 \\
\hline $\begin{array}{l}\text { Desalination and Water } \\
\text { Treatment }\end{array}$ & 1.272 & 50 & 0.01143 & 13 & 0.392 & 13 & 28 & 26 \\
\hline $\begin{array}{l}\text { International Journal of } \\
\text { Disaster Risk } \\
\text { Reduction }\end{array}$ & 1.242 & 51 & 0.00062 & 68 & 0.599 & 68 & 19 & 42 \\
\hline $\begin{array}{l}\text { Journal of } \\
\text { Hydroinformatics }\end{array}$ & 1.18 & 52 & 0.00227 & 39 & 0.731 & 39 & 21 & 37 \\
\hline $\begin{array}{l}\text { Lake and Reservoir } \\
\text { Management }\end{array}$ & 1.1 & 53 & 0.00081 & 61 & 0.57 & 61 & 13 & 61 \\
\hline $\begin{array}{l}\text { Water Science and } \\
\text { Technology }\end{array}$ & 1.064 & 54 & 0.01566 & 8 & 0.469 & 8 & 33 & 15 \\
\hline Water International & 1.04 & 55 & 0.00104 & 58 & 0.464 & 58 & 17 & 47 \\
\hline $\begin{array}{l}\text { Canadian Water } \\
\text { Resources Journal }\end{array}$ & 1.018 & 56 & 0.00076 & 62 & 0.539 & 62 & 12 & 64 \\
\hline Water Policy & 0.952 & 57 & 0.00177 & 44 & 0.505 & 44 & 17 & 47 \\
\hline $\begin{array}{l}\text { International Journal of } \\
\text { Disaster Risk Science }\end{array}$ & 0.935 & 58 & 0.00046 & 72 & 0 & 72 & 14 & 58 \\
\hline $\begin{array}{l}\text { Journal of Pipeline } \\
\text { Systems Engineering } \\
\text { and Practice }\end{array}$ & 0.896 & 59 & 0.00056 & 69 & 0.416 & 69 & 10 & 72 \\
\hline $\begin{array}{l}\text { Water and Environment } \\
\text { Journal }\end{array}$ & 0.895 & 60 & 0.00131 & 52 & 0.478 & 52 & 19 & 42 \\
\hline $\begin{array}{l}\text { Mine Water and the } \\
\text { Environment }\end{array}$ & 0.864 & 61 & 0.00053 & 71 & 0.382 & 71 & 12 & 64 \\
\hline Water Sa & 0.851 & 62 & 0.00166 & 47 & 0.381 & 47 & 16 & 52 \\
\hline $\begin{array}{l}\text { Ground Water } \\
\text { Monitoring and } \\
\text { Remediation }\end{array}$ & 0.848 & 63 & 0.00083 & 60 & 0.372 & 60 & 15 & 54 \\
\hline $\begin{array}{l}\text { Journal of Water } \\
\text { Supply Research and } \\
\text { Technology-Aqua }\end{array}$ & 0.807 & 64 & 0.00084 & 59 & 0.399 & 59 & 12 & 64 \\
\hline $\begin{array}{l}\text { Journal of Water } \\
\text { Sanitation and Hygiene } \\
\text { for Development }\end{array}$ & 0.799 & 65 & 0.00064 & 65 & 0.394 & 65 & 12 & 64 \\
\hline $\begin{array}{l}\text { Journal of Water and } \\
\text { Climate Change }\end{array}$ & 0.775 & 66 & 0.00063 & 67 & 0.363 & 67 & 12 & 64 \\
\hline $\begin{array}{l}\text { Water Environment } \\
\text { Research }\end{array}$ & 0.659 & 67 & 0.00222 & 40 & 0.334 & 40 & 20 & 39 \\
\hline $\begin{array}{l}\text { Proceedings of The } \\
\text { Institution of Civil } \\
\text { Engineers-Water } \\
\text { Management }\end{array}$ & 0.656 & 68 & 0.00163 & 48 & 0.524 & 48 & 17 & 47 \\
\hline
\end{tabular}


-ibres volume 27, issue 2, pages 97-111 (2017)

\begin{tabular}{|c|c|c|c|c|c|c|c|c|}
\hline \multirow[b]{2}{*}{ Journal } & \multicolumn{2}{|c|}{$\begin{array}{l}\text { Journal Impact } \\
\text { Factor (JIF) }\end{array}$} & \multicolumn{2}{|c|}{$\begin{array}{l}\text { Eigenfactor } \\
\text { Score (ES) }\end{array}$} & \multicolumn{2}{|c|}{$\begin{array}{l}\text { SCImago } \\
\text { Journal Rank } \\
\text { (SJR) }\end{array}$} & \multicolumn{2}{|c|}{ H-5 Index } \\
\hline & Value & Rank & Value & Rank & Value & Rank & Value & Rank \\
\hline $\begin{array}{l}\text { Soil and Water } \\
\text { Research }\end{array}$ & 0.58 & 69 & 0.00027 & 76 & 0.27 & 76 & 9 & 73 \\
\hline Irrigation and Drainage & 0.565 & 70 & 0.00117 & 56 & 0.409 & 56 & 14 & 58 \\
\hline $\begin{array}{l}\text { Water Science and } \\
\text { Technology-Water } \\
\text { Supply }\end{array}$ & 0.532 & 71 & 0.0013 & 53 & 0.315 & 53 & 13 & 61 \\
\hline $\begin{array}{l}\text { Water Quality Research } \\
\text { Journal of Canada }\end{array}$ & 0.531 & 72 & 0.00039 & 73 & 0.263 & 73 & 8 & 74 \\
\hline $\begin{array}{l}\text { Journal American } \\
\text { Water Works } \\
\text { Association }\end{array}$ & 0.505 & 73 & 0.00145 & 50 & 0.38 & 50 & 15 & 54 \\
\hline Grundwasser & 0.436 & 74 & 0.00023 & 78 & 0.267 & 78 & 8 & 74 \\
\hline $\begin{array}{l}\text { China Ocean } \\
\text { Engineering }\end{array}$ & 0.435 & 75 & 0.00064 & 65 & 0.422 & 65 & 0 & 82 \\
\hline $\begin{array}{l}\text { Journal of Water Reuse } \\
\text { and Desalination }\end{array}$ & 0.409 & 76 & 0.00027 & 76 & 0.221 & 76 & 8 & 74 \\
\hline $\begin{array}{l}\text { Membrane Water } \\
\text { Treatment }\end{array}$ & 0.4 & 77 & 0.0002 & 80 & 0.313 & 80 & 6 & 78 \\
\hline $\begin{array}{l}\text { Hydrologie Und } \\
\text { Wasserbewirtschaftung }\end{array}$ & 0.39 & 78 & 0.00038 & 74 & 0.295 & 74 & 3 & 81 \\
\hline Water Resources & 0.31 & 79 & 0.0007 & 64 & 0.281 & 64 & 8 & 74 \\
\hline $\begin{array}{l}\text { Proceedings of the } \\
\text { Institution of Civil } \\
\text { Engineers-Maritime } \\
\text { Engineering }\end{array}$ & 0.281 & 80 & 0.00018 & 81 & 0.149 & 81 & 0 & 82 \\
\hline $\begin{array}{l}\text { Houille Blanche-Revue } \\
\text { Internationale De L Eau }\end{array}$ & 0.212 & 81 & 0.00023 & 78 & 0.15 & 78 & 0 & 82 \\
\hline $\begin{array}{l}\text { Engenharia Sanitaria E } \\
\text { Ambiental }\end{array}$ & 0.126 & 82 & 0.00018 & 81 & 0.15 & 81 & 11 & 69 \\
\hline Wasserwirtschaft & 0.102 & 83 & 0.00016 & 83 & 0.205 & 83 & 5 & 79 \\
\hline $\begin{array}{l}\text { Tecnologia Y Ciencias } \\
\text { Del Agua }\end{array}$ & 0.043 & 84 & 0.00008 & 84 & 0.169 & 84 & 4 & 80 \\
\hline $\begin{array}{l}\text { Environmental Science- } \\
\text { Water Research and } \\
\text { Technology }\end{array}$ & 0 & 85 & 0.00001 & 85 & 0 & 85 & 0 & 82 \\
\hline
\end{tabular}

